\begin{tabular}{ccc}
\hline & International Journal of Advanced Geosciences, 8(1)(2020)65-74 \\
SPC & Website: www.sciencepubco.com/index.php/IJAG \\
\hline
\end{tabular}

\title{
Evaluation of groundwater resources within Ankpa and environ, north central Nigeria
}

\author{
Omali A.O ${ }^{1 *}$, Usman A.O ${ }^{2}$, Baba Y ${ }^{1}$ \\ ${ }^{1}$ Department of Earth Sciences, Kogi State University, Anyigba, Nigeria \\ ${ }^{2}$ Department of Physics/Geology/Geophysics Alex Ekweme Federal University, Ndufu-Alike, Ikwo, Ebonyi State \\ *Corresponding author E-mail: ayatuusman@gmail.com
}

\begin{abstract}
Geophysical and Geochemical assessment of groundwater in part of Northern Anambra Basin has been evaluated. The groundwater potentials, aquifer characteristics and groundwater quality within the study area have been delineated. This is aimed is at establishing the depth to watertable and potability of the groundwater within the area. Twenty-(20) vertical electrical soundings (VES) were acquired with a maximum half current electrode spacing of 150 metres using ABEM 4000 SAS Tetrameter. Hydrogeochemical analysis was carried out using HANA Model Hi 83200 multi parameter ion specific meter to evaluate the basic anions and cations in the water samples. Piper, Durov and Schoeller semi-logarithmic plots were drawn to characterize the water types. Results from the geo-electric sections revealed the presence of five to seven geo-electric layers. The depth to water table ranges between $20 \mathrm{~m}$ and $161.1 \mathrm{~m}$. The depth to Watertable is deepest around Ogene area with depth of $161.1 \mathrm{~m}$. The result of the geophysical analysis correlates with the borehole data acquired from the study area. Results from hydrogeochemical studies revealed that the concentrations of ions are in the order of $\mathrm{Ca}^{2+}>\mathrm{Na}^{2+}>\mathrm{K}^{+}>\mathrm{Mg}^{2+}$ and $\mathrm{HCO}_{3}-$ $>\mathrm{NO}_{3}{ }_{3}>\mathrm{SO}_{4}{ }^{2-}>\mathrm{Cl}^{-}$in Anyigba area, $\mathrm{Na}^{2+}>\mathrm{K}^{+}>\mathrm{Ca}^{2+}>\mathrm{Mg}^{2}$ and $\mathrm{Cl}^{-}>\mathrm{HCO}_{3}->\mathrm{NO}_{3}->\mathrm{SO}_{4}^{2-}$ Ankpa area while in Ejule area $\mathrm{Mg}^{2+}>\mathrm{Na}^{2+}>\mathrm{K}^{+}>$ $\mathrm{Ca}^{2+}$ and $\mathrm{Cl}^{-}>\mathrm{HCO}_{3}->\mathrm{NO}_{3}->\mathrm{SO}_{4}{ }^{2-}$. These fall within the WHO (2006) drinking water standard. It is recommended that an average depth of $75 \mathrm{~m}$ should be drilled for borehole within the northern part of the studied area and a depth of about $100 \mathrm{~m}$ in the southern part of the study area. In addition, the water is recommended for domestic use.
\end{abstract}

Keywords: Groundwater Potentials; Water Types; Aquifer Characterization; Piper Diagram and Potability.

\section{Introduction}

Groundwater availability is also as important as portability since water is of great economical value. Hence, there is a great need to evaluate the groundwater resources of the study area (Omali., 2014 and Alile, et al 2008). Consequently, the increase in population of people as a result of increase in Industrial, Educational and Agricultural activities and inaccessibility of the inhabitants to potable water necessitates this study.

The study area falls within the Northern Anambra basin. It is bounded by Longitudes $7^{0} 00^{1} 00^{11} \mathrm{~N}$ and $7^{0} 45^{1} 00^{11} \mathrm{~N}$ and latitudes $6^{0} 45^{1} 00^{11} \mathrm{E}$ and $07^{0} 45^{1} 00^{11} \mathrm{E}$ (Fig.1). There are available surface water such as Okura, Ofu and Mabolo rivers among others which are tributaries to the River Niger. Water supply to the growing population is mainly by surface water schemes because of limited boreholes. It is against this background that the study becomes necessary.

The objectives include: Determination of the geo-electrical and hydro-geological characteristics of the aquifers, geochemical assessment of the surface and groundwater, delineation of the water types, aquifer thickness and their geometries, determination of potential aquiferous layers and boundaries from the geo-electric sections, correlate the geo-electric sections/VES curves with various rock lithologies from well $\operatorname{logs}$ and relate them to aquifer potentials and to compare the differences in the hydraulic properties of the geologic formations underlying the study area.. Again, there are scanty literature and very limited or no detailed data on water resources and long term yield capabilities of aquifers within the study area. Most of available water schemes in the area are obsolete, making the accessibility to groundwater resources within the area in terms of availability and quality to be very difficult. 


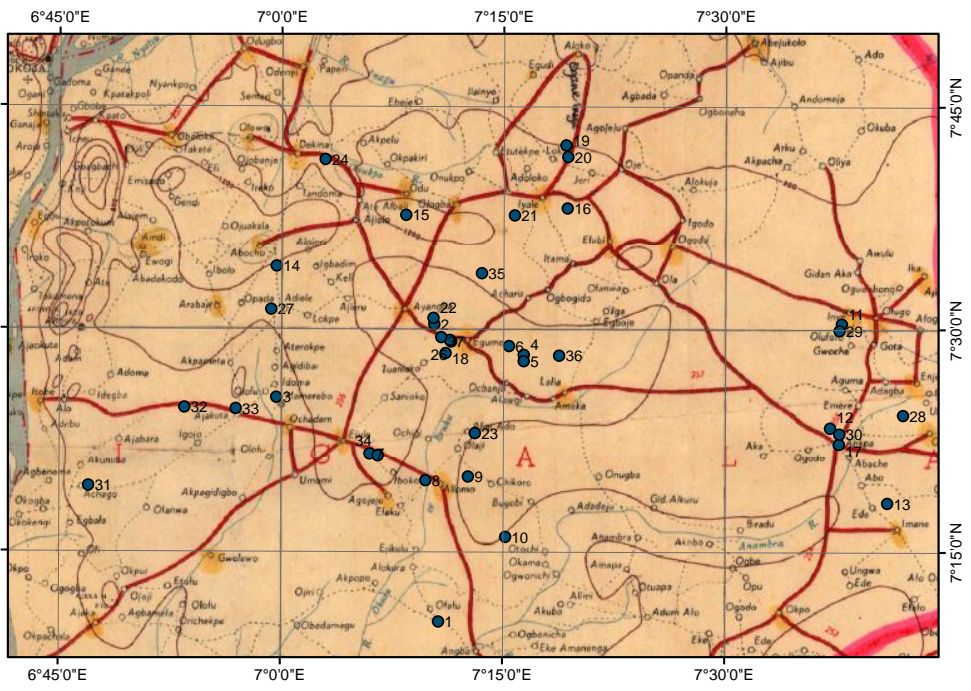

Fig. 1: Accessibility Map of the Study Area (Omali, Et Al, 2018).

\section{Geology and hydrogeology of the study area}

The Anambra Basin is one of the Nigerian's most important sedimentary basins and comprises an almost triangular shaped embayment covering an area of about 30,000 $\mathrm{Km}^{2}$ (Offodile,2002) (Fig. 2). The sequence of depositional events demonstrates a progressively deepening of the Anambra basin, from lower coastal plain shoreline deltas to shoreline and shallow marine deposits. According to Obaje (2009), sedimentation in the Anambra Basin commenced with the Campanian - Maastrichtian marine paralic shales of the Enugu/Nkporo Formations.

The fluvio - deltaic sandstones of the Ajali and Owelli Formation which lie on the Mamu Formation constitute its lateral equivalents in most places. The sandstone unit is white in colour, coarse grained and poorly sorted. Constituent pebbles are well rounded while finer grains are sub - rounded. The composite thickness of the Owelli Formation is approximately 50m around Owelli. The most important aquiferous formation in the Anambra Basin is the Ajali Formation, consisting of a heterogeneous lithological sequence. The Anyigba area is overlain by the Ajali Formation. The sandstone beds of the Ajali Formation are confined in places and have produced artesian conditions. According to Kogbe (1989), the Nsukka Formation overlies the Ajali Formation conformably. Good exposures of the Nsukka Formation are rare except around some of the areas west of Nsukka and it consists of an alternating sequence of laminated, very fine sandstone and siltstones. There are also brown and grey shales and sandy shales and mudstone with numerous coal seams at various horizons. The Nsukka Formation was not noticed in the study area, is overlain conformably by the Ajali sandstone (Upper Maastrichtian). These Formations collectively consists of the following lithologic units in the study area: shale, clay, whitish sand, reddish sand, brownish sand, laterites, ferruginised sandstones and alluvial deposits.

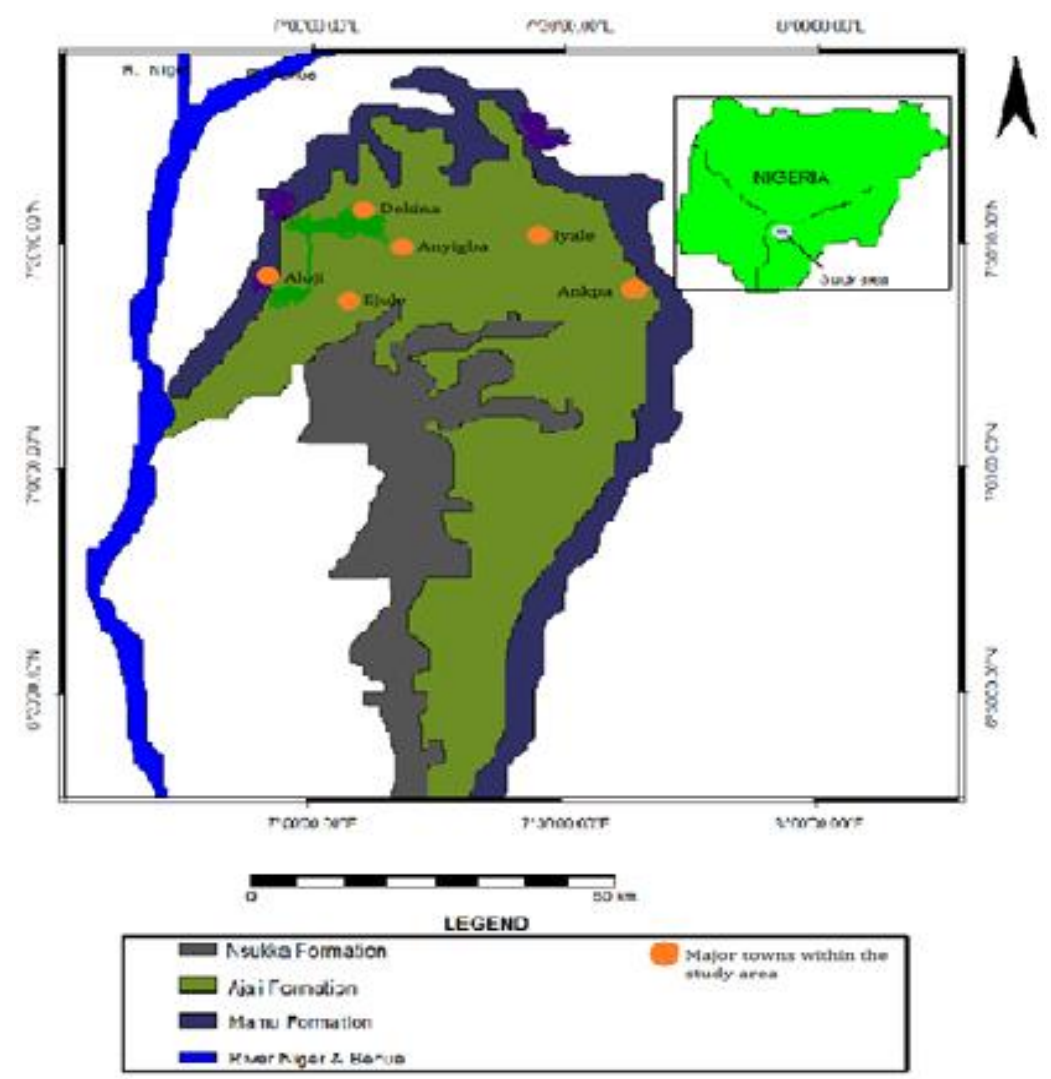

Fig. 2: Geological Map of Anambra Basin Showing the Study Area (modified from Umeji, 2005). 


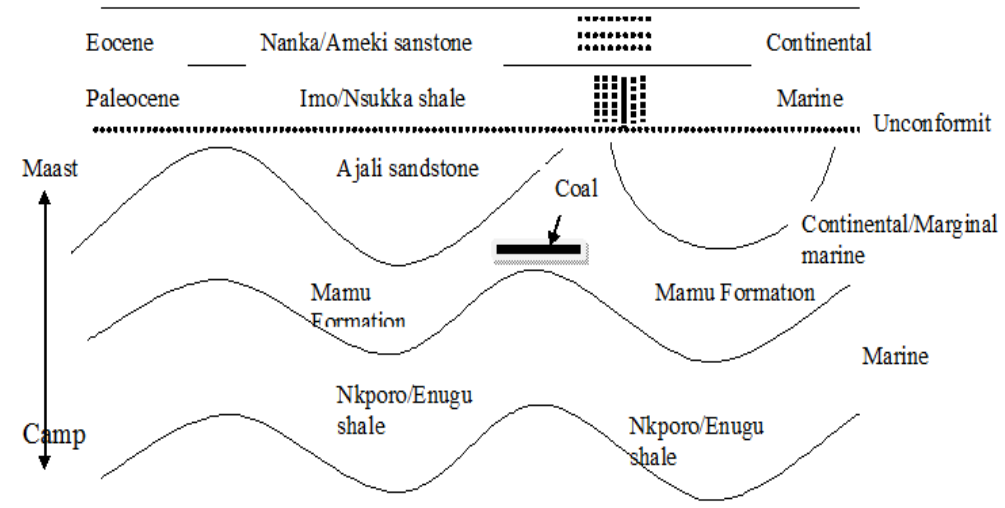

Fig. 3: Stratigraphic Successions in the Anambra Basin (After Obaje, 2009).

\section{Method of study}

Groundwater assessment within part of Kogi East, Northern Anambra Basin has been carried out using Geophysical and Geochemical techniques. Geophysical investigation was done using vertical electrical sounding (Schlumberger method) to delineate the subsurface resistivity by sending an electrical current into the subsurface and measuring the potential field generated by the current on the resistivity meter (Tetrameter). Vertical Electrical Sounding (VES) was conducted at twenty-two stations in the study area using Schlumberger configuration. The maximum half-current electrode spacing $(\mathrm{AB} / 2)$ ranges from 250 to $500 \mathrm{~m}$. The survey was conducted along the existing major and minor roads with good stretch and at the vicinity of existing boreholes in the study area.

Vertical Electrical sounding using Schlumberger array was carried out by keeping the electrode array centered over a field station while increasing the spacing between the current electrodes and consequently increasing the depth of investigation. The potential difference $(\Delta \mathrm{V})$ and the electrical current $(\mathrm{I})$ are measured for each electrode spacing and the apparent resistivity $\left(\rho_{\mathrm{a}}\right)$ is calculated by the equation 1 below.

$$
\rho_{a}=G \frac{\Delta v}{I}(o h m-m)
$$

Where, $\boldsymbol{\rho}_{\boldsymbol{a}}=$ Apparent resistivity of the aquiferous layer; $\mathrm{G}=$ the geometric factor of the electrode arrangement; $\Delta \mathrm{v}=$ potential difference; $\mathrm{I}=$ current

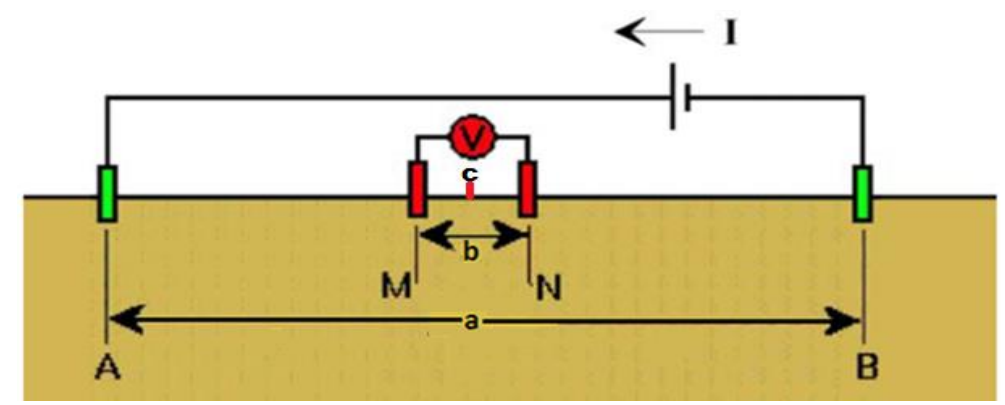

Fig. 4: Diagrammatic Representation of Schlumberger Array.

By repeating the Schlumberger measurements with the entire setup moved one step to the side, vertical electrical sounding (VES) were performed continuously and the resistivities of the subsurface layers were measured. A plot of apparent resistivity $\left(\boldsymbol{\rho}_{\boldsymbol{a}}\right)$ against current electrodes spacing was plotted on a bilogarithimic graph.

The apparent resistivity data are associated with varying depths relative to the distance between the current and potential electrodes and can be interpreted qualitatively and quantitatively in terms of lithologic and or geo-electric models.

23 samples of Groundwater were collected from boreholes within the study area at the peak of the dry season to prevent dilution effect of precipitation and contamination associated with storm water runoff (Thomson, 1996). Each sampling bottle was allowed to get filled to the brim and capped. Parameters such as Temperature, colour, Total Dissolved Solid (TDS), Dissolved Oxygen (DO), pH and Electrical conductivity were taken at each location in the field for all the water samples using HANA model HI 83200 multi parameter ion specific meter, $\mathrm{pH}$ meter and conductivity meter respectively. Furthermore, 0.5 liters of water samples were taken for laboratory analyses. The samples were protected from heat and contamination by chemicals. Cationic compositions were determined using Atomic Absorption Spectrophotometer (model 210 VGP) at the Department of Earth Sciences, Kogi state university Anyigba. The concentration of anions such as No3 and $\mathrm{Cl}^{-}$were determined by titrimetric method in the Geochemistry laboratory of the University. Results of the analyses are presented in tables 4, 5 and 6. The chemistry of the water samples are plotted on Piper, Durov and Schoeller diagrams (figures 9-17).

\section{Results, interpretation, and discussion}

\subsection{Geophysical results and interpretations}

The interpretation of the resistivity data of the twenty (20) stations represented as V1-V20 shows basically five to six geo-electric horizons. However eight (8) out of the twenty VESs were made at the sites of the existing boreholes for comparative purposes to check the efficiency of this method. Below are detailed descriptions of some of the VES results. 
VES 1: (Fig. 5 and Table 1) has five geo-electric layers. The sounding curve at this station is of AKH model. The first layer comprises the topsoil, $5.5 \mathrm{~m}$ thick and has resistivity of $169 \Omega \mathrm{m}$. The second layer is composed of laterite of thickness and depth $12.2 \mathrm{~m}$ and $17.2 \mathrm{respec}-$ tively. The resistivity of this layer is $394.2 \Omega \mathrm{m}$. The third layer can be interpreted as sandstone, the depth of this zone is $55 \mathrm{~m}$, with thickness of $37.8 \mathrm{~m}$ and resistivity of $2801.3 \Omega \mathrm{m}$. The fourth layer is interpreted as fairly saturated to saturated sandstone to a depth of $126 \mathrm{~m}$ with thickness of $71.0 \mathrm{~m}$ and resistivity of $1002.9 \mathrm{~m}$. Underlying this unit has a high conductivity value and it is interpreted as impermeable clay. VES 4: The first layer consists of topsoil which has a thickness of $2.5 \mathrm{~m}$ and resistivity of $257.92 \Omega \mathrm{m}$. The second layer is composed of laterite with thickness of $5.0 \mathrm{~m}$ at a depth of $2.5 \mathrm{~m}$ and resistivity of $13051.7 \Omega \mathrm{m}$. The third layer is mainly sandstone with thickness of $33.8 \mathrm{~m}$ at a depth of $38.8 \mathrm{~m}$ and resistivity value of $11876 . \Omega \mathrm{m}$. This is followed by the fourth layer which is fairly saturated sandstone layer with thickness of $37.9 \mathrm{~m}$ and at a depth of $54.2 \mathrm{~m}$ and resistivity value of $59967.3 \Omega \mathrm{m}$. Underlying which is the fifth layer is a compacted saturated sandstone layer with a resistivity of $56301.9 \Omega \mathrm{m}$.

VES 7: Six horizons are delineated in Fig. 7 and Table 3. The uppermost layer has a resistivity value of $198.9 \Omega-\mathrm{m}$ and $1.95 \mathrm{~m}$ thick. It is interpreted as top lateritic soil. The second layer has a resistivity value of $535.9 \Omega-\mathrm{m}$ and a thickness of $7.26 \mathrm{~m}$ which is interpreted as sandy clay. The third layer has a resistivity value of $3364.7 \Omega-\mathrm{m}$ with thickness of $3.0 \mathrm{~m}$ and interpreted as clayey sand. The forth layer has a very high resistivity value of $53356 \Omega-\mathrm{m}$ with thickness of $140.22 \mathrm{~m}$. It is interpreted as dry sandstone. The fifth layer has a thickness of $20 \mathrm{~m}$ and has moderate resistivity value of $2231 \Omega-\mathrm{m}$. It is interpreted as water saturated sandstone which is the prospective aquifer of interest. The sixth layer whose base was not reached has a resistivity value of $621 \Omega-\mathrm{m}$ and interpreted as clayey sand.

VES 16: Six geo-electric sections were delineated in this location (Fig.8 and Table 4). The topmost layer has a resistivity value of $721.0 \Omega-$ $\mathrm{m}$ which is $0.5 \mathrm{~m}$ thick and interpreted as top lateritic soil. The second layer has a high resistivity value of $1121 \Omega-\mathrm{m}$ and a thickness of 0.8 metres which is interpreted as sandstone. The third layer has a resistivity value of $1321 \Omega-\mathrm{m}$ with thickness of $57 \mathrm{~m}$ and interpreted as sandy shale. The forth layer has a very high resistivity value of $19813 \Omega-\mathrm{m}$ with high thickness of $30 \mathrm{~m}$. It is interpreted as dry sandstone. The fifth layer has a thickness of about $30 \mathrm{~m}$ and has a relatively moderate resistivity value of $2210 \Omega-\mathrm{m}$. It is interpreted as water saturated sandstone which is the prospective aquifer of interest. The last layer whose base was not reached has low resistivity value of $431.2 \Omega-m$ and interpreted as sandy clay.

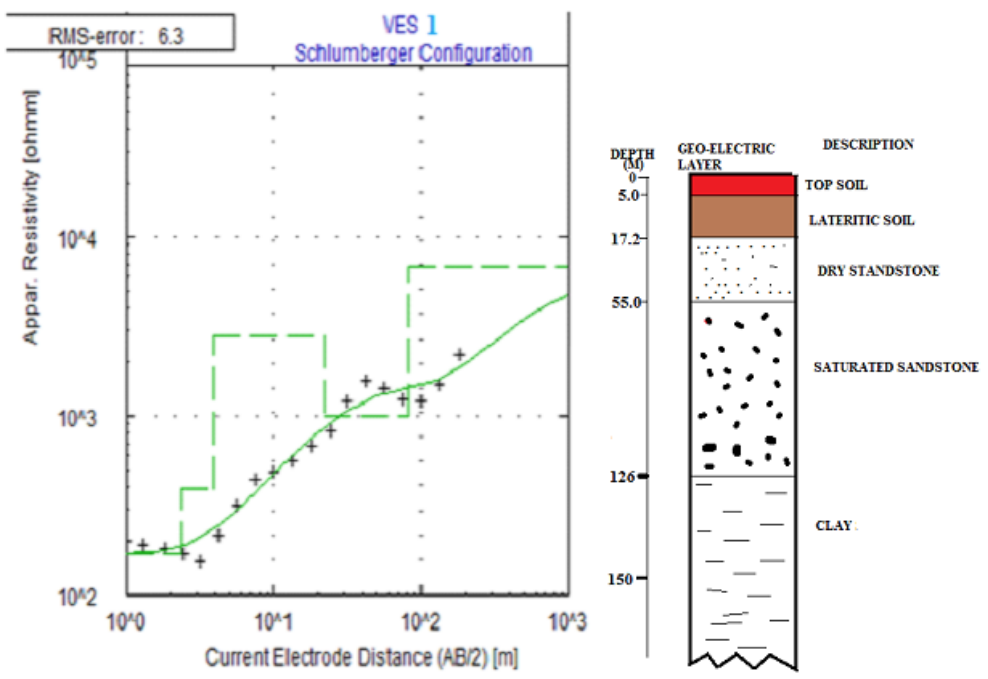

Fig. 5: Sounding Curve and Descriptive Section for VES 1 (AKH-Type).

Table 1: Geo-Electric Section of VES 1

\begin{tabular}{lllll}
\hline VES 1 & \multicolumn{4}{c}{ Table 1: Geo-Electric Section of VES 1 } \\
Layer & $\boldsymbol{\rho}_{a}(\boldsymbol{\Omega} \boldsymbol{m})$ & Thickness $(\mathrm{m})$ & Depth & Remarks \\
\hline 1 & I69 & 5.0 & 5.0 & Top soil \\
2 & 394.2 & 12.2 & 17.2 & Lateritic sand \\
3 & 2801.3 & 37.8 & 55.00 & Dry sandstone \\
4 & 1002.9 & 71.0 & 126 & Water Saturated Sst. \\
5 & 1,125 & Base Not & Clayey \\
& & Reached & & \\
\hline
\end{tabular}

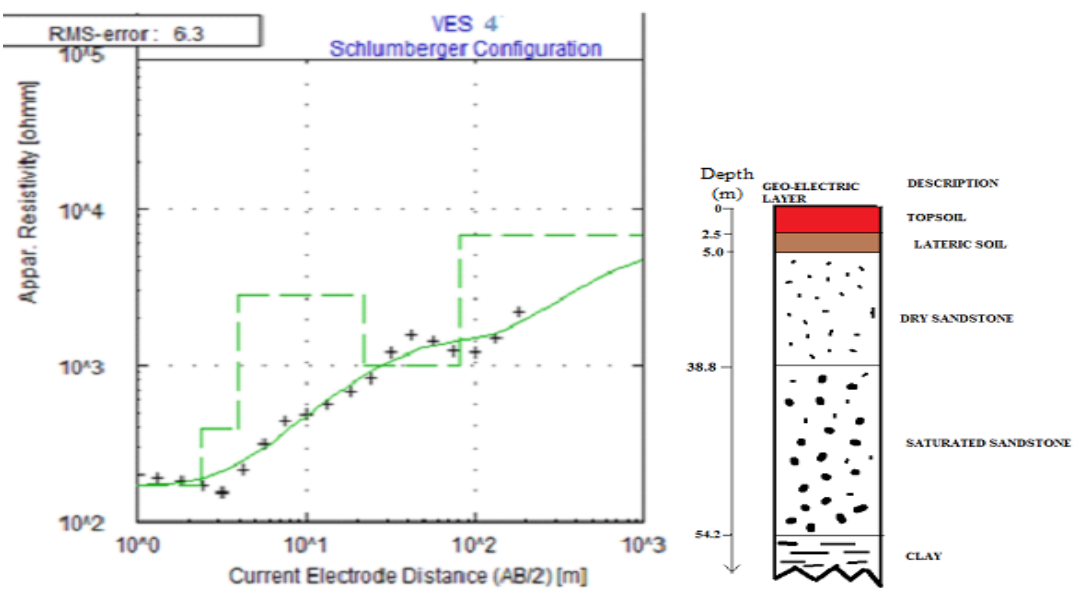

Fig. 6: Sounding Curve and Descriptive Section for VES 4 (KHA-Type). 
Table 2: Geo-Electric Section of VES 4

\begin{tabular}{|c|c|c|c|c|}
\hline $\begin{array}{l}\text { VES } 4 \\
\text { Layer }\end{array}$ & $\rho_{a}(\Omega m)$ & Thickness(m) & Depth & Remarks \\
\hline 1 & 257.92 & 0.5 & 0.5 & Top soil \\
\hline 2 & 13051.7 & 1.9 & 2.4 & Lateritic sand \\
\hline 3 & 11876.5 & 13.8 & 16.2 & Dry sandstone \\
\hline 4 & 9967.3 & 37.9 & 54.2 & Water Saturated Sst. \\
\hline 5 & 56301.9 & Base Not Reached & & Clayey Sandstone \\
\hline
\end{tabular}
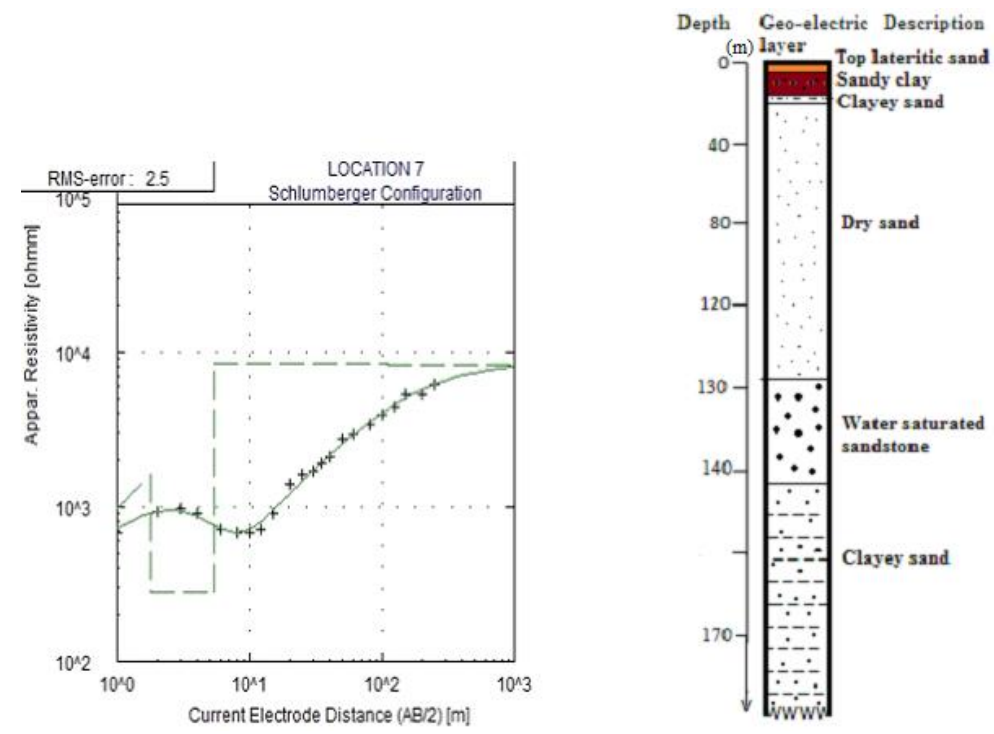

Fig. 7: Sounding Curve and Descriptive Section for VES 7 (K-Type).

Table 3: Geo-Electric Section of VES 7

\begin{tabular}{lllll}
\hline VES 7 & \multicolumn{4}{c}{ Table 3: Geo-Electric Section of VES 7 } \\
Layer & $\boldsymbol{\rho}_{a}(\boldsymbol{\Omega m})$ & Thickness $(\mathrm{m})$ & Depth $(\mathrm{m})$ & Remarks \\
\hline 1 & 198.9 & 1.95 & 1.95 & Top lateritic sand \\
2 & 544.9 & 7.26 & 9.21 & Sandy clay \\
3 & 3244.7 & 3.00 & 12.21 & Clayey sand \\
4 & 61356 & 140.13 & 158.34 & Dry sand \\
5 & 2161 & 20.0 & 178.34 .0 & Water Saturated sand \\
6 & 621 & Base Not Reached & & Clayey sand \\
\hline
\end{tabular}

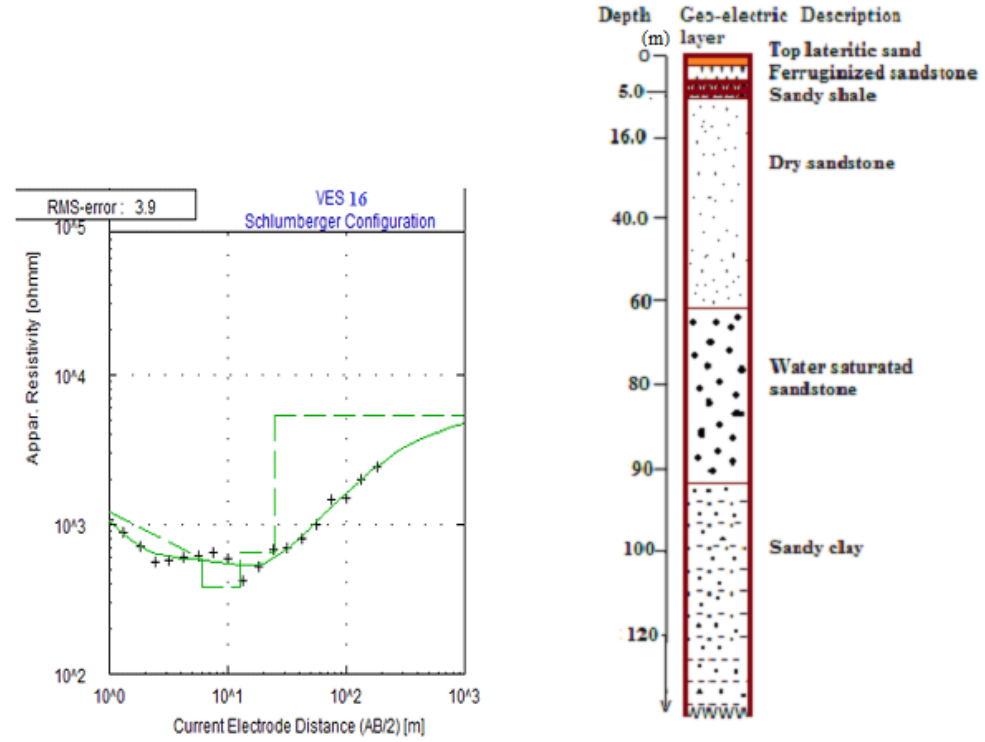

Fig. 8: Sounding Curve and Descriptive Section for VES 16 (K-Type).

Table 4: Geo-Electric Section of VES 16

\begin{tabular}{|c|c|c|c|c|}
\hline $\begin{array}{l}\text { VES } 16 \\
\text { Layer }\end{array}$ & $\rho_{a}(\Omega m)$ & Thickness(m) & $\operatorname{Depth}(\mathrm{m})$ & Remarks \\
\hline 1 & 721.0 & 0.50 & 0.50 & Lateritic sand \\
\hline 2 & 1121 & 0.8 & 1.30 & Ferruginised Sst. \\
\hline 3 & 1321 & 3.7 & 5.0 & Sandy shale \\
\hline 4 & 19813 & 57.0 & 62.0 & Dry Sandstone \\
\hline 5 & 2210.0 & 30.0 & 92.0 & Water Saturated sand \\
\hline 6 & 431.2 & Base not Reached & & Sandy Clay \\
\hline
\end{tabular}




\section{Geochemical analysis of the water samples}

\subsection{Hydrogeochemical result (facies)}

The results of the physio-chemical analysis of water samples collected from Anyigba, Ankpa and Ejule areas are presented in tables 5, 6 and 7 below.

Table 5: Summary of Physical and Chemical Parameters of Groundwater in Anyigba Area.

\begin{tabular}{|c|c|c|c|c|c|c|c|c|c|}
\hline \multirow[b]{2}{*}{ Locations } & \multicolumn{8}{|c|}{ Borehole Sources } & \multirow[b]{2}{*}{$\begin{array}{l}\text { Nigeria Stand- } \\
\text { ard (2005) }\end{array}$} \\
\hline & $\begin{array}{l}\text { Specific } \\
\text { Eatary }\end{array}$ & Ajetachi & $\begin{array}{l}\text { K.S.U Main } \\
\text { Borehole }\end{array}$ & Egume & Ogene & Ijoji & Who Standar & (2006) & \\
\hline \multirow{4}{*}{ G.P.S Readings } & N7²9' & N7²9' & N7²9' & N7²8' & N7²8 & N7²7' & \multirow{4}{*}{$\begin{array}{l}\text { High Desir- } \\
\text { able Level }\end{array}$} & \multirow{4}{*}{$\begin{array}{l}\text { Maximum Per- } \\
\text { missible Level }\end{array}$} & \multirow{4}{*}{$\begin{array}{l}\text { Maximum Per- } \\
\text { mitted Level }\end{array}$} \\
\hline & $16.6 ”$ & $43.0^{\prime}$ & $06.0 ”$ & $15.8^{\prime}$ & $51.2^{\prime}$ & $450.2^{\prime}$ & & & \\
\hline & E7 ${ }^{\bullet} 10^{\prime}$ & E7 ${ }^{\circ} 10^{\prime}$ & E7 ${ }^{*} 10^{\prime}$ & E7 ${ }^{\circ} 16^{\prime}$ & E7 ${ }^{\circ} 15^{\prime}$ & E7 ${ }^{\bullet} 6^{\prime}$ & & & \\
\hline & $42.5^{\prime}$ & 18.0, & $51.0 ”$ & $25.6 "$ & $26.2^{\prime}$ & $47.6^{\prime}$ & & & \\
\hline Colour & Clear & Clear & Clear & Clear & Clear & Clear & 5 & 50 & 15 \\
\hline $\mathrm{Ph}$ & 6.6 & 6.5 & 6.5 & 6.6 & 6.5 & 6.6 & $7.0-8.5$ & $6.5-9.2$ & $6.5-8.5$ \\
\hline $\operatorname{Temp}^{\circ} \mathrm{c}$ & 28.5 & 28.0 & 27.5 & 28.0 & 28.5 & 28.0 & $\mathrm{Na}$ & $\mathrm{Na}$ & Ambient \\
\hline $\begin{array}{l}\text { Electrical Con- } \\
\text { ductivity } \mu \mathrm{c} / \mathrm{Cm}\end{array}$ & 0.02 & 0.02 & 0.01 & 0.03 & 0.03 & 0.02 & $\mathrm{Na}$ & 250 & 1000 \\
\hline T.D.S Mg/L & 14 & 23 & 16 & 22 & 20 & 19 & 500 & 1500 & 500 \\
\hline D.O & 3.05 & 3.06 & 3.26 & 3.02 & 3.18 & 3.16 & $\mathrm{Na}$ & $\mathrm{Na}$ & $\mathrm{Na}$ \\
\hline \multicolumn{10}{|l|}{ Cations (Mg/L) } \\
\hline $\mathrm{K}^{+}$ & 0.18 & 0.20 & 0.22 & 0.20 & 1.12 & 1.09 & 10 & 15 & $\mathrm{Na}$ \\
\hline $\mathrm{Mg}^{2+}$ & 0.05 & 0.04 & 0.07 & 0.20 & 0.12 & 0.05 & 50 & 150 & 0.20 \\
\hline $\mathrm{Fe}^{2+}$ & 0.05 & 0.04 & 0.07 & 0.20 & 0.12 & 0.05 & 0.1 & 1.0 & 0.3 \\
\hline $\mathrm{Na}^{2+}$ & 0.31 & 0.47 & 0.23 & 0.24 & 0.25 & 0.20 & 150 & 200 & 200 \\
\hline $\mathrm{Cu}^{2+}$ & 0.03 & 0.03 & 0.04 & 0.03 & 0.03 & 0.04 & 0.05 & 1.5 & 1 \\
\hline $\mathrm{Ca}^{2+}$ & 0.92 & 0.87 & 1.02 & 1.10 & 1.10 & 0.85 & 75 & 200 & $\mathrm{Na}$ \\
\hline $\mathrm{Zn}^{2+}$ & $\mathrm{Nd}$ & $\mathrm{Nd}$ & $\mathrm{Nd}$ & $\mathrm{Nd}$ & $\mathrm{Nd}$ & $\mathrm{Nd}$ & 5.0 & 15 & 3 \\
\hline \multicolumn{10}{|l|}{ Anions $(\mathrm{Mg} / \mathrm{L})$} \\
\hline $\mathrm{No}_{3-}$ & 10.30 & 10.34 & 10.21 & 10.70 & 11.13 & 10.23 & 45 & 50 & 50 \\
\hline $\mathrm{So}_{4}{ }^{2-}$ & 7.01 & 7.98 & 8.63 & 8.02 & 7.09 & 6.82 & 200 & 400 & 100 \\
\hline $\mathrm{Cl}-$ & 0.065 & 0.067 & 0.068 & 0.066 & 0.072 & 0.069 & 200 & 600 & 250 \\
\hline $\mathrm{HcO}_{3}{ }^{-}$ & 98.11 & 99.86 & 101.95 & 99.01 & 91.06 & 89.42 & 200 & 600 & $\mathrm{Na}$ \\
\hline
\end{tabular}

$\mathrm{NA}=$ Not applicable $\mathrm{ND}=$ Not detected.

Table 6: Summary of Physical and Chemical Parameters of Groundwater in Ankpa Area.

\begin{tabular}{|c|c|c|c|c|c|c|c|c|c|c|c|c|c|}
\hline \multirow{2}{*}{ Locations } & \multicolumn{5}{|c|}{ Borehole Source } & \multicolumn{2}{|c|}{ Spring Source } & \multicolumn{3}{|c|}{ Shallow Water Source } & \multicolumn{2}{|c|}{ Who Standards (2006) } & \multirow{2}{*}{$\begin{array}{l}\text { Nigeria } \\
\text { Standads } \\
(2005) \\
\text { Maximum } \\
\text { Permitted } \\
\text { Level }\end{array}$} \\
\hline & Ankpa & Coe & $\begin{array}{l}\text { Sa- } \\
\text { bima }\end{array}$ & $\begin{array}{l}\text { Itodo } \\
\text { Compd. }\end{array}$ & $\begin{array}{l}\text { Mu- } \\
\text { naja }\end{array}$ & Ikebe & Imane & $\begin{array}{l}\text { Ojede } \\
1\end{array}$ & $\begin{array}{l}\text { Ojode } \\
\text { Ii }\end{array}$ & $\begin{array}{l}\text { Sabon } \\
\text { Gari }\end{array}$ & $\begin{array}{l}\text { De- } \\
\text { sira- } \\
\text { ble } \\
\text { Level }\end{array}$ & $\begin{array}{l}\text { Maximum } \\
\text { Permissible } \\
\text { Level }\end{array}$ & \\
\hline Colour & Clear & Clear & Clear & Clear & Clear & Clear & Clear & Clear & Clear & Clear & 5 & 50 & 15 \\
\hline $\mathrm{Ph}$ & 6.0 & 6.5 & 6.80 & 6.1 & 6.21 & 6.95 & 6.98 & 5.58 & 5.56 & & $\begin{array}{l}7.0- \\
8.5\end{array}$ & $6.5-9.2$ & $6.5-8.5$ \\
\hline $\begin{array}{l}\text { Temp }{ }^{\circ} \mathrm{c} \\
\text { Electrical }\end{array}$ & 26 & 26 & 25 & 25.5 & 26 & 24 & 25 & 27 & 27 & & $\mathrm{Na}$ & $\mathrm{Na}$ & Ambient \\
\hline $\begin{array}{l}\text { Conductiv- } \\
\text { ity } \\
\mu \mathrm{s} / \mathrm{Cm}\end{array}$ & 1277 & 0.52 & 211 & 103 & .59 & .17 & .15 & 283 & 202 & & $\mathrm{Na}$ & 250 & 1000 \\
\hline $\begin{array}{l}\text { T.D.S } \\
\mathrm{Mg} / \mathrm{L}\end{array}$ & 84.2 & 0.51 & 0.43 & 0.43 & 0.39 & 164.0 & 164.1 & .51 & 169.0 & & 500 & 1500 & 500 \\
\hline D.O & $\mathrm{Nd}$ & $\mathrm{Nd}$ & $\mathrm{Nd}$ & $\mathrm{Nd}$ & $\mathrm{Nd}$ & $\mathrm{Nd}$ & $\mathrm{Nd}$ & $\mathrm{Nd}$ & $\mathrm{Nd}$ & & $\mathrm{Na}$ & $\mathrm{Na}$ & $\mathrm{Na}$ \\
\hline $\mathrm{K}^{+}$ & 26.15 & 0.066 & 1.330 & 0.203 & 0.286 & 0.127 & 0.126 & 1.997 & 1770 & 0811 & 10 & 15 & $\mathrm{Na}$ \\
\hline $\mathrm{Mg}^{2+}$ & 6.692 & 0.119 & 0.682 & 0.181 & 0.283 & 0.073 & 0.065 & 0.892 & 0.827 & 0.592 & 50 & 150 & 0.20 \\
\hline $\mathrm{Fe}^{2+}$ & 0.015 & 0.016 & 0.013 & 0.015 & 0.014 & 0.009 & 0.007 & 0.007 & 0.016 & 0.012 & 0.1 & 1.0 & 0.3 \\
\hline $\mathrm{Na}^{2+}$ & 49.6 & 1.144 & 5.556 & 0.479 & 0.566 & 0.328 & 0.324 & 10.48 & 3.967 & 2.825 & 150 & 200 & 200 \\
\hline $\mathrm{Cu}^{2+}$ & 0.003 & 0.011 & 0.006 & 0.006 & 0.021 & 0.001 & 0.001 & 0.000 & 0.001 & 0.001 & 0.05 & 1.5 & 1 \\
\hline $\mathrm{Ca}^{2+}$ & 16.44 & 0.515 & 2.269 & 5.296 & 1.436 & 0.495 & 0.466 & 3.405 & 4.273 & 1.801 & 75 & 200 & $\mathrm{Na}$ \\
\hline $\mathrm{Zn}^{2+}$ & 0.12 & 0.00 & 0.00 & 0.00 & 0.00 & 0.00 & 0.00 & 0.00 & 0.00 & 0.00 & 5.0 & 15 & 3 \\
\hline \multicolumn{14}{|c|}{ Anions $(\mathrm{Mg} / \mathrm{L})$} \\
\hline $\mathrm{No}_{3-}$ & 0.98 & 0.24 & 0.21 & 0.31 & 0.49 & 1.84 & 1.80 & 0.42 & 1.69 & 0.43 & 45 & 50 & 50 \\
\hline $\mathrm{So}_{4}{ }^{2-}$ & 21.6 & 11.0 & 10.1 & 11.2 & 12.3 & 49.6 & 44.5 & 2.1 & 48.6 & 11.2 & 200 & 400 & 100 \\
\hline $\mathrm{Cl}-$ & 112.2 & 62.3 & 80.1 & 64.2 & 46.1 & 204.2 & 202.0 & 76.1 & 212.4 & 69.5 & 200 & 600 & 250 \\
\hline $\mathrm{HcO}_{3}{ }^{-}$ & 104.1 & 0.81 & 0.69 & 0.98 & 1.08 & 212.2 & 201.2 & 1.16 & 214.1 & 1.02 & 200 & 600 & $\mathrm{Na}$ \\
\hline
\end{tabular}

NA $=$ Not applicable ND $=$ Not detected.

Table 7: Summary of Physical and Chemical Parameters of Groundwater in Ejule Area.

\begin{tabular}{|c|c|c|c|c|c|c|}
\hline & Borehole Sourc & & & & & \\
\hline Locations & $\begin{array}{l}\text { Marist College } \\
\text { Ejule }\end{array}$ & Ejule Town & Iboko & Ofabo & Who Standards (2006) & Nigeria Standard (2005) \\
\hline
\end{tabular}




\begin{tabular}{|c|c|c|c|c|c|c|c|}
\hline G.P.S Readings & $\begin{array}{l}\text { N7'29' } 16.6^{\prime}, \\
\text { E7'10'42.5', }\end{array}$ & $\begin{array}{l}\mathrm{N} 7{ }^{\circ} 29^{\prime} \\
43.0^{\prime}, \\
\mathrm{E} 7^{\circ} 10^{\prime} \\
18.0^{\prime},\end{array}$ & $\begin{array}{l}\text { N7 }{ }^{\circ} 29^{\prime} 06.0, \\
\text { E7 }{ }^{\circ} 10^{\prime} 51.0^{\prime},\end{array}$ & $\begin{array}{l}\mathrm{N} 7{ }^{\circ} 28^{\prime} \\
15.8^{\prime}, \\
\mathrm{E} 7{ }^{\circ} 16^{\prime} \\
25.6^{\prime}\end{array}$ & $\begin{array}{l}\text { High Desir- } \\
\text { able Level }\end{array}$ & $\begin{array}{l}\text { Maximum } \\
\text { Permissible } \\
\text { Level }\end{array}$ & Maximum Permitted Level \\
\hline Colour & Clear & Clear & Clear & Clear & 5 & 50 & 15 \\
\hline $\mathrm{Ph}$ & 6.32 & 6.33 & 6.50 & 6.50 & $7.0-8.5$ & $6.5-9.2$ & $6.5-8.5$ \\
\hline $\mathrm{Temp}^{\circ} \mathrm{c}$ & $25 \cdot \mathrm{C}$ & $25.5 \cdot \mathrm{C}$ & $26.0 \cdot \mathrm{C}$ & $26 \cdot \mathrm{C}$ & $\mathrm{Na}$ & $\mathrm{Na}$ & Ambient \\
\hline $\begin{array}{l}\text { Electrical Con- } \\
\text { ductivity } \\
\mu \mathrm{s} / \mathrm{Cm}\end{array}$ & 0.71 & 0.66 & 0.52 & 0.47 & $\mathrm{Na}$ & 250 & 1000 \\
\hline T.D.S Mg/L & 102.0 & 96.2 & 101.5 & 88.2 & 500 & 1500 & 500 \\
\hline $\begin{array}{l}\text { D.O } \\
\text { Cations }(\mathrm{Mg} / \mathrm{L})\end{array}$ & $\mathrm{Nd}$ & $\mathrm{Nd}$ & $\mathrm{Nd}$ & $\mathrm{Nd}$ & $7.0-8.5$ & $6.5-9.2$ & $6.5-8.5$ \\
\hline $\mathrm{K}^{+}$ & 4.6 & 4.3 & 4.8 & 3.8 & 10 & 15 & $\mathrm{Na}$ \\
\hline $\mathrm{Mg}^{2+}$ & 15.8 & 15.1 & 14.7 & 14.3 & 50 & 150 & 0.20 \\
\hline $\mathrm{Fe}^{2+}$ & 0.02 & 0.02 & 0.03 & 0.03 & 0.1 & 1.0 & 0.3 \\
\hline $\mathrm{Na}^{2+}$ & 3.4 & 3.0 & 3.3 & 3.8 & 150 & 200 & 200 \\
\hline $\mathrm{Cu}^{2+}$ & 0.012 & 0.013 & 0.008 & 0.006 & 0.05 & 1.5 & 1 \\
\hline $\mathrm{Ca}^{2+}$ & 12.2 & 11.6 & 12.8 & 13.1 & 75 & 200 & $\mathrm{Na}$ \\
\hline $\begin{array}{l}\mathrm{Zn}^{2+} \\
\text { Anions }(\mathrm{Mg} / \mathrm{L})\end{array}$ & $\mathrm{Nd}$ & $\mathrm{Nd}$ & $\mathrm{Nd}$ & $\mathrm{Nd}$ & 5.0 & 15 & 3 \\
\hline $\mathrm{No}_{3-}$ & 12.86 & 11.92 & 10.77 & 13.31 & 45 & 50 & 50 \\
\hline $\mathrm{So}_{4}{ }^{2-}$ & 8.22 & 7.91 & 6.89 & 7.46 & 200 & 400 & 100 \\
\hline $\mathrm{Cl}-$ & 52.10 & 53.5 & 38.6 & 44.8 & 200 & 600 & 250 \\
\hline $\mathrm{HcO}_{3}{ }^{-}$ & 7.73 & 8.02 & 9.66 & 9.05 & 200 & 600 & $\mathrm{Na}$ \\
\hline
\end{tabular}

$\mathrm{NA}=$ Not applicable.

$\mathrm{ND}=$ Not detected

\subsection{Water quality and usability}

\subsubsection{Physical parameters}

$\mathrm{pH}$ of groundwater samples in Anyigba area ranges between 6.5 to 6.6, in Ankpa and environs it varies from 5.56 to 6.98 whereas, in Ejule area, the water samples recorded $\mathrm{pH}$ values of between 6.32 and 6.50. These values fall within the World Health Organization (WHO) and Standard Organization of Nigeria (SON) maximum permissible level for drinking water. The electrical conductivity values in these areas range between 0.01 to $0.03 \mu \mathrm{s} / \mathrm{cm}, 15$ to $127703 \mu \mathrm{s} / \mathrm{cm}$ and 0.47 to $0.7103 \mu \mathrm{s} / \mathrm{cm}$ respectively. These values are within the WHO $(250 \mu \mathrm{s} / \mathrm{cm})$ and SON $(1000 \mu \mathrm{s} / \mathrm{cm})$ permitted levels.

In addition, the total dissolved solids (TDS) in the sampled areas recorded values ranging from $14 \mathrm{mg} / \mathrm{l}$ to $23 \mathrm{mg} / \mathrm{lin}$ Anyigba area, $0.39 \mathrm{mg} / 1$ to $169 \mathrm{mg} / \mathrm{l}$ in Ankpa axis and $88.2 \mathrm{mg} / \mathrm{l}$ to $102 \mathrm{mg} / \mathrm{l}$ in Ejule area. These Fall below WHO and SON guidelines for potable water (tables 5 , 6 , and 7)

\subsubsection{Cationic concentration}

Cationic concentrations in the water samples from Anyigba area include; Potassium $\mathrm{K}^{+} 0.18$ to $1.12 \mathrm{mg} / \mathrm{l}, \mathrm{Magnesium} \mathrm{Mg}^{2+}$, 0.04 to $0.12 \mathrm{mg} / \mathrm{l}$, Iron $\mathrm{Fe}^{2+} 0.0$ to $0.12 \mathrm{mg} / 1$, sodium $\mathrm{Na}^{2+}, 0.20$ to $0.47 \mathrm{mg} / \mathrm{l}$, and Calcium $\mathrm{Ca}^{2+}$, $0 . .85$ to $1.10 \mathrm{mg} / 1$. All the analyzed cations fall within the standards for potable water by WHO and SON. This also applies to the samples collected from Ankpa and Ejule areas (tables 6 and 7).

\subsubsection{Anionic concentration}

Nitrate $\left(\mathrm{NO}_{3}{ }^{-}\right)$concentration varies from 10.23 to $11.13 \mathrm{mg} / \mathrm{l}$ in water samples collected from Anyigba area. In Ankpa area it ranges from 0.21 to $1.8 \mathrm{mg} / \mathrm{l}$, while in Ejule area, it recorded values ranging from 10.77 to $13.31 \mathrm{mg} / \mathrm{l}$. These values are in tandem with the maximum permissible levels of $50 \mathrm{mg} / \mathrm{l}$ stated in the tables above. Also, bicarbonate $\left(\mathrm{HCO}_{3}{ }^{-}\right)$concentrations range between $89.42 \mathrm{mg} / 1$ to $101.95 \mathrm{mg} / 1$, , 0.69 to $214.1 \mathrm{mg} / 1$ and 7.73 to $9.66 \mathrm{mg} / 1$ respectively. These cations and others including sulphate $\left(\mathrm{SO}_{4}{ }^{2-}\right)$ and $\mathrm{Chloride}\left(\mathrm{Cl}^{-}\right)$in the areas studied are within the acceptable limits for both the WHO and SON for drinking water. Hence, the groundwater in the study area is fit for domestic use.

\subsection{Results of piper diagrams, durov diagrams and schoeller semi-logarithmic plots}

Piper trilinear, Durov and Schoeller diagrams were generated for groundwater within the study area (Fig. 9 to 17). Hence, the groundwater and the surface water composition and character were determined. Akakuru et al (2015) noted that during groundwater movement along its path, from recharge to discharge areas, a variety of chemical reactions with solid phases take place. They maintained that these chemical reactions vary spatially and temporally, depending on the chemical nature of the initial water, geological formations, and residence time. The resulting concentrations of major ions of groundwater can be used to identify the intensity of rock-water interaction and chemical reactions.

From the hydrochemical plots in figures 9 to 17, different chemical characters have been established. The groundwater from Anyigba area indicated $\mathrm{Ca}-\mathrm{HCO}_{3}{ }^{-}$water type. This represents recently recharged water of meteoric origin that resulted from the dissolution of alluminosilicates. In Ankpa area, the groundwater sample indicated $\mathrm{Na}+\mathrm{K}-\mathrm{Cl}$ water type. This reflects fossil water whose origin is natural and anthropogenic

In Ejule and environs, $\mathrm{Ca}-\mathrm{Cl}$ and $\mathrm{Mg}-\mathrm{Cl}$ water types have been established from plots on piper and Durov diagrams. This reflects water of intermediate compositions that evolved by simple hydrochemical mixing and reverse ion exchange. Also, the presence of chloride $\left(\mathrm{Cl}^{-}\right)$is an indication of the old water contained in a deep aquifer.

However, changes in the chemistry of groundwater occur as the water moves from shallow zones of acting flushing through intermediate zones into zones where the flow is very sluggish and the water is old. However, this sequence must be looked into in terms of the scale and geology of the area, with allowances for interruption and incompletion. 


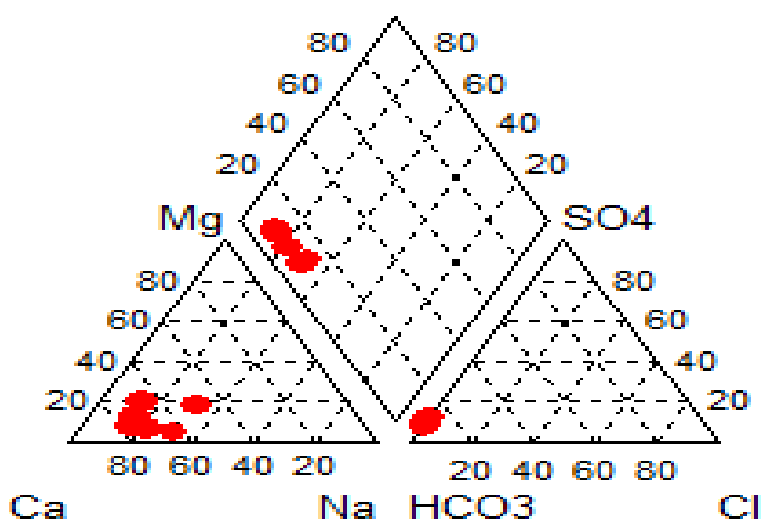

Fig. 9: Piper Trilinear Diagram Plot of Water Samples in Anyigba Area Showing Ca- $\mathrm{HCO}_{3}$ Water Type.

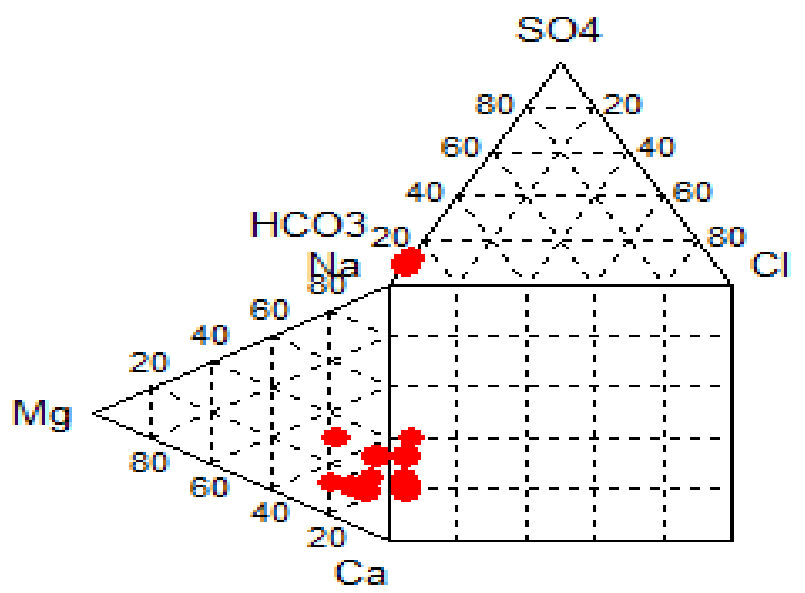

Fg 10: Durov Diagram Plot of Water Samples in Anyigba Area Showing $\mathrm{Ca}-\mathrm{HCO}_{3}$ Water Type.

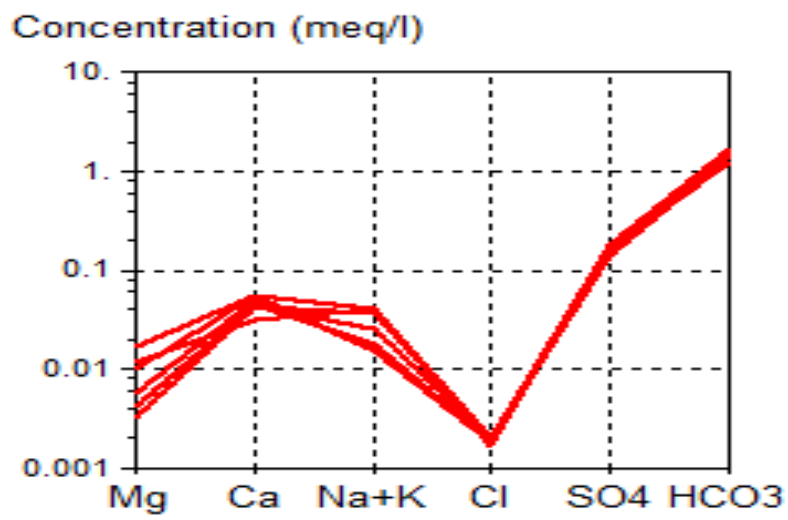

Fig. 11: Schoeller Semi-Logarithmic Plot of Water Samples in Anyigba Area Showing A Trend of $\mathrm{Hco}_{3}>\mathrm{So}_{4}>\mathrm{Ca}>\mathrm{Na}+\mathrm{K}>\mathrm{Mg}>\mathrm{Cl}$

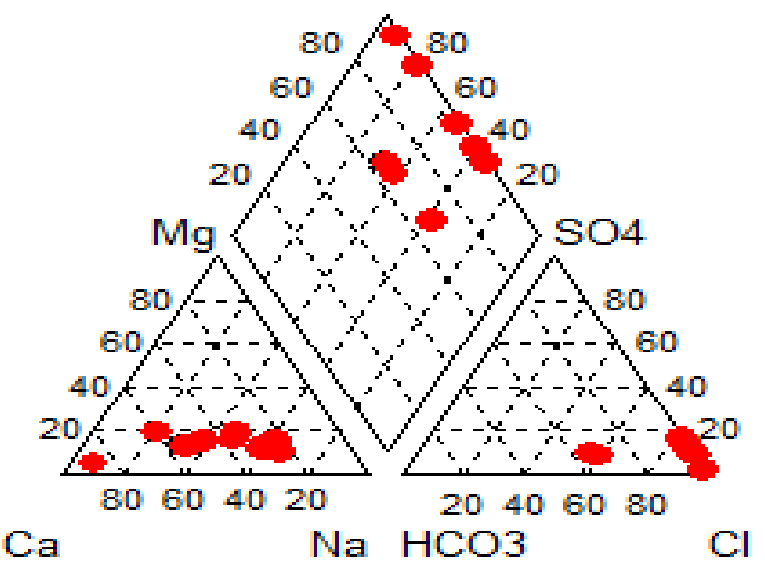

Fig. 12: Piper Trilinear Diagram Plot of Water Samples in Ankpa Area Showing Na+K-Cl Water Type. 


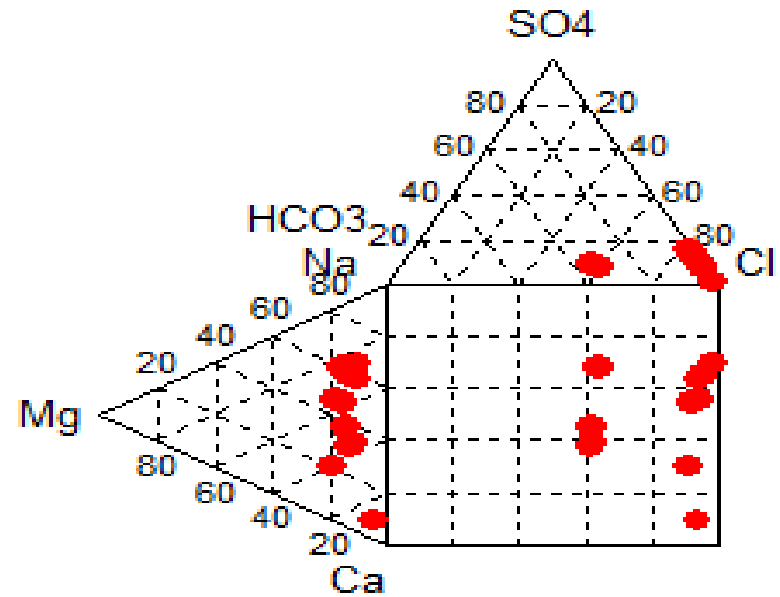

Fig. 13: Durov Diagram Plot of Water Samples in Ankpa Area Showing $\mathrm{Na}^{+}+\mathrm{K}-\mathrm{Cl}$ Water Type.

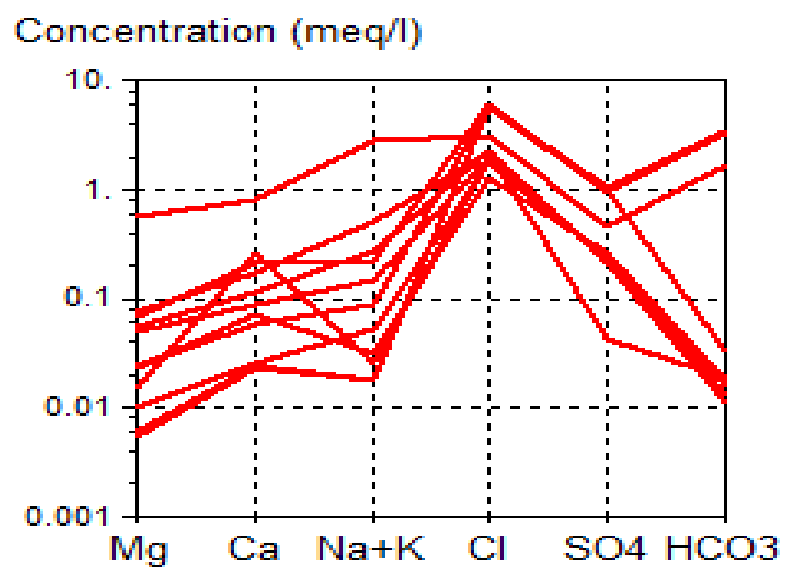

Fig. 14: Schoeller Semi-Logarithmic Plot of Water Samples in Ankpa Area Showing A Trend of $\mathrm{Cl}>\mathrm{HCO}_{3}>\mathrm{SO}_{4}>\mathrm{Na}+\mathrm{K}>\mathrm{Ca}>\mathrm{Mg}$.

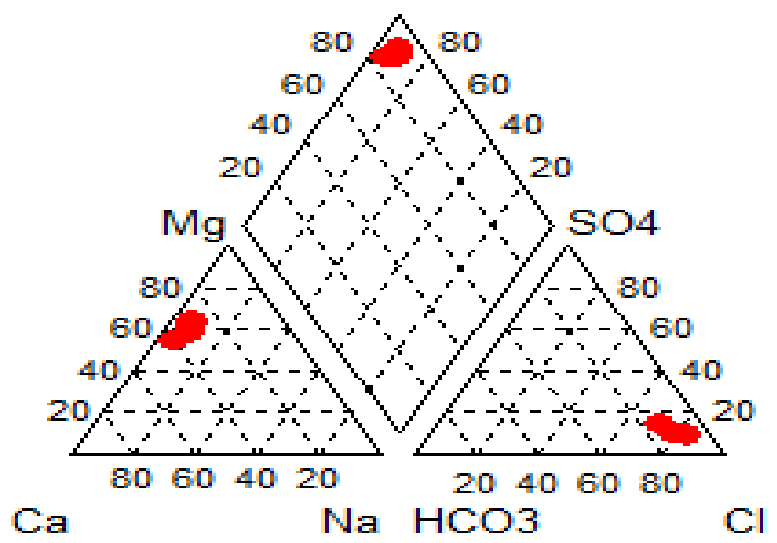

Fig. 15: Piper Trilinear Diagram Plot of Water Samples in Ejule Area Showing Ca-Cl Water Type.

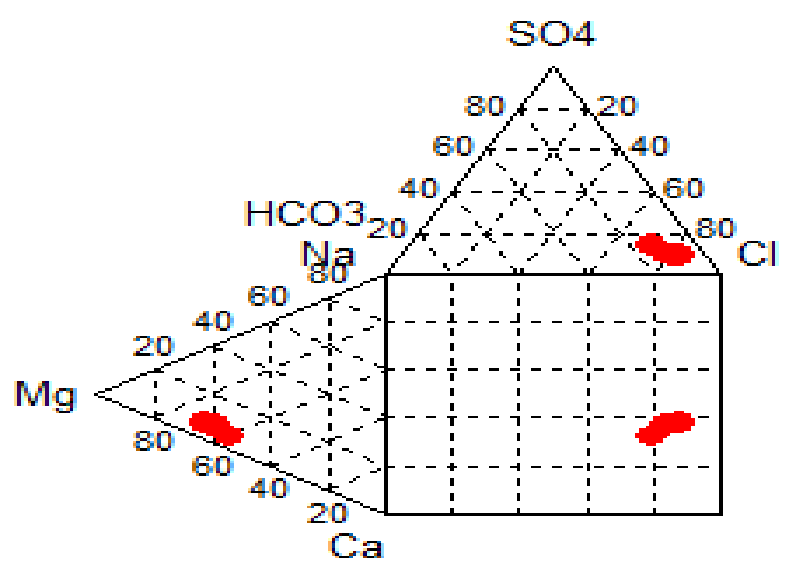

Fig. 16: Durov Diagram Plot of Water Samples in Ejule Area Showing Mg-Cl Water Type. 


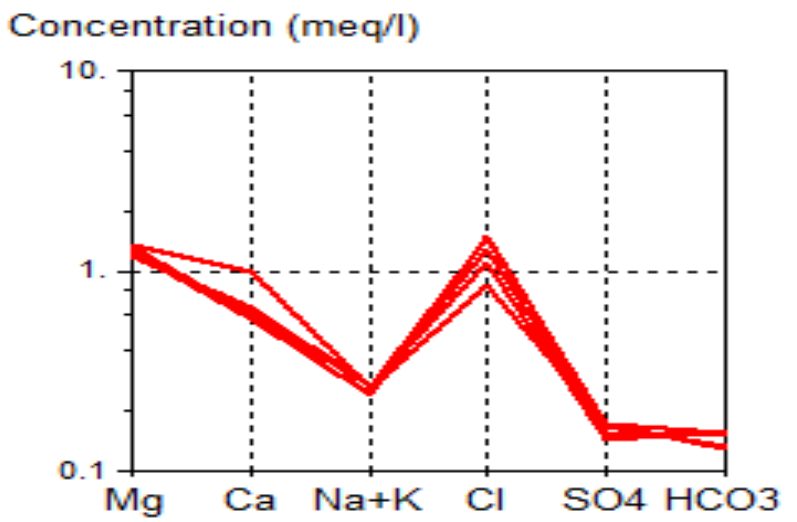

Fig. 17: Schoeller Semi-Logarithmic Plot of Water Samples in Ejule Area Showing A Trend of $\mathrm{Cl}>\mathrm{Mg}>\mathrm{Ca}>\mathrm{Na}+\mathrm{K}>\mathrm{SO}_{4}>\mathrm{HCO}_{3}$

\section{Conclusions and summary}

Analysis from the hydrogeochemical studies reveals that the concentration values of $\mathrm{Na}^{2+}, \mathrm{Ca}^{2+}, \mathrm{Zn}^{2+}, \mathrm{SO}_{4}{ }^{3-}, \mathrm{Cl}^{-}$and $\mathrm{NO}_{3}{ }^{-}$in the three water samples analyzed fall within the WHO (2006) drinking water standard. From the hydrogeochemical plots, there exist similarity in water type, between the water sources; this suggests that similar geochemical processes may be controlling major ion chemistry in these aquifers, and that the waters had the same or similar origins. Schoeller semi logarithm diagram shows that the surface water in the study area is not of one dominant type. The close to parallel lines of the Schoeller diagram for groundwater portrays it to be composed of equal ratio of ions, thus of one dominant type, while the surface water is not.

The modeled interpretation from computer analysis revealed the presence of five to seven geo-electric layers. The layer resistivity is a function of porosity, moisture content present in the pore spaces and the rock matrix. The depth to water table in the study area varies between $20 \mathrm{~m}$ and $151.1 \mathrm{~m}$ and the aquifer thickness was revealed to be highest in Ogene, Acbocho and Egume areas. The depth to Watertable is deepest around Ogene area.

\section{References}

[1] Akakuru, O.C., Akudinobi, B.E.B., and Aniwetalu, E.U (2015) Qualitative evaluation and hydrogeochemical attributes of groundwater in Owerri Capital Territory, Southeastern Nigeria, IOSR journal of Applied Geology and Geophysics, 3(2). www.iosrjournals.org. 12- 18

[2] Akpabio, I., and Ekpo, E., 2008. "Geoelectric Investigation for Groundwater Development of Southern Part of Nigeria". Pacific Journal of Science and Technology. vol. 9, no.1, pp. 219-226.

[3] Alile M.O, Jegede S.I, and Ehigiator O.M., 2008. Underground water exploration using electrical resistivity method in Edo State, Nigeria, Asian J. Earth Sci., vol. 1, no. 1, pp38-42. https://doi.org/10.3923/ajes.2008.38.42.

[4] Hem, J.D. (1985). Study and Interpretation of the chemical characteristics of Natural Water: US Geological Survey Water-supply paper 2254/p263.

[5] Kogbe, C.A., (1989). The Cretaceous and Paleogene Sediments of Southern Nigeria. Geology of Nigeria $2^{\text {nd }}$ Edition. Rock View (Nig) Ltd, pp. $325-$ 334.

[6] Obaje, N. G. (2009). Geology and mineral resources of Nigeria. $1^{\text {st }}$ edition Springer Books, Heidelberg. pp 60-62. https://doi.org/10.1007/978-3-54092685-6.

[7] Offodile M. E. (2002). Groundwater study and development in Nigeria. $2^{\text {nd }}$ edition. Published by Mecon geology and engineering services L.t.d. $452 \mathrm{p}$.

[8] Okoro, E.I., Egboka, B.C.E. and Onwuemesi, A.G., 2010. Evaluation of the aquifer characteristic of Nanka Sands using hydrogeological method in combination with Vertical Electrical Sounding (VES). J. Appl. Sci. Environ. Mgt. vol. 14, no. 2, pp 5-9 https://doi.org/10.4314/jasem.v14i2.57822.

[9] Onu, N.N. and Ibezim, C.U. 2004. Hydrogeophysical investigation of Southern Anambra Basin Nigeria. African Journals on-line. https://doi.org/10.4314/gjgs.v2i2.18699.

[10] Onwuemesi, A.G., and B.C.E., Egboka, 2006. 2-D Polynomial curve fitting techniques on watertable, and hydraulic gradients estimations in parts of Anambra Basin, Southeastern Nigeria,Natural and Applied Sci. J., vol. 7, no. 1\&2, pp 6-13.

[11] Omali, A.O. (2014) Hydrogeophysical Investigation for Groundwater in Lokoja Metropolis, Kogi State, Central Nigeria. Journal of Geography and Geology; Vol. 6, No. 1; pp 81-95 https://doi.org/10.5539/jgg.v6n1p81.

[12] Omali, A.O., Usman, A.O and Oguche, I.I. (2018). Hydrogeophysical Evaluation of Groundwater Resources within some parts of Northern Anambra Basin, Nigeria. Journal of Earth Sciences and Geotechnical Engineering, vol. 8, no. 4, 2018, pp17-33.

[13] Piper, A.M., (1953). A graphical procedure in the Geochemical Interpretation of water Analysis. United State Geological Survey Bulletin 45, pp. 7579.

[14] Nigeria Standard for drinking water quality; ICS Nigeria Industrial Standard NIS 554:2005.

[15] Thomson, N., (1996). Combating Groundwater contamination from runoffs in urban areas, Groundwater notes, vol.9, no.1, p. 6, Waterloo Centre for Groundwater Research, University of Waterloo.

[16] Umeji, P. O. (2005). Palynological study of the Okaba coal section in the Anambra Basin, Southern Nigeria, Journal of Mining and Geol. 41(2), pp. 194.

[17] WHO (2006)? http://www.who.int/watersanitationhealth/dwq/gdwq0506.pdf. 